\title{
Pengaruh Stress dan Kecemasan Terhadap Kinerja Perawat Ruang Isolasi Covid-19 yang Menggunakan Ventilator di Lantai 6 Gedung Anggrek RSUP Fatmawati
}

\author{
Shinta ${ }^{1}$, Cicilia Windiyaningsih ${ }^{2}$, Alih Germas Kodyat ${ }^{3}$ \\ Universitas Respati Indonesia \\ Email: shinta.lenggo@gmail.com
}

\begin{abstract}
Abstrak
Latar belakang: Perawat merupakan salah satu garda terdepan dalam penanganan wabah Corona Virus Deases-19 (Covid-19) yang melanda dunia, termasuk Indonesia. Produktifitas dan kinerja perawat harus terjaga dengan baik selama pandemic dengan menjalankan asuhan keperawatan, yang meliputi bidang promotif, preventif, kuratif dan rehabilitatif. Rumah sakit, sebagai institusi kesehatan harus berusaha menjaga kinerja perawat yang dipengaruhi oleh factor internal dan eksternal, termasuk kondisi atau keadaan psikologis. Penelitian ini bertujuan untuk menganalisa pengaruh kecemasan, stress terhadap kinerja perawat di ruang isolasi Covid 19 Gedung Anggrek RSUP Fatmawati 2020. Metode: Penelitian ini menggunakan desain kuantitatif deskriptif analitik dengan pendekatan cross sectional. Populasi dalam penelitian ini berjumlah 105 orang, dengan jumlah sampel sebanyak 51 responden berdasarkan formula dari Taro Yamane. Sampel ditentukan dengan teknik random sampling. Hasil: Penelitian ini menunjukkan bahwa uji korelasi variabel stress terhadap kinerja memiliki pengaruh yang signifikan dengan nilai Asymp. Sig 0,002 <0,05. Kecemasan terhadap kinerja memiiki pengaruh yang signifikan dengan nilai Asymp. Sig 0,001<0,05. Pengaruh stress dan kecemasan secara simultan terhadap kinerja dengan nilai Asymp. Sig 0,007 $<0,05$ yang berarti signifikan antara stress dan kecemasan terhadap kinerja. Diskusi: variabel stress dan kecemasan memliki pengaruh yang signifikan terhadap kinerja. Nilai koefisien stress dan kecemasan bernilai negative terhadap kinerja.
\end{abstract}

Kata Kunci : Stres, Kecemasan, Kinerja, Perawat, Covid 19.

\section{Abstract}

Introduction: The latest case of the Corona Deases-19 (Covid-19) Virus in the world, near Indonesia, has recently been reported. Nurses' productivity and performance must be properly maintained during a pandemic by carrying out nursing care, which includes the fields of promotive, preventive, curative and rehabilitative. The hospital, as overtime, must maintain the nurse's performance as seen by internal and external factors, including psychological conditions or conditions. This study aims to analyze the effect of stress on the performance of nurses in the Covid 19 isolation room, Gedung Anggrek, Fatmawati Hospital 2020. Method: The research method used was a descriptive quantitative analytic design with a cross sectional approach. The prison system population is 105 people, with a sample size of 51 respondents based on the formula from Taro Yamane. The sample is determined by a random sampling technique. Result: The data shows that the stress variable testing on performance has a significant effect on the Asymp value. Sig $0.002<0.05$. Performance anxiety has a significant 
effect on the Asymp value. Sig $0.001<0.05$. The effect of stress and assessment simultaneously on performance with the Asymp value. Sig $0.007<0.05$, which means that there is a significant difference between stress and criticism of performance.

Discussion: stress and weight loss variables are significant signs of anxiety. Value of stress coefficient and negative value on performance.

Keywords: Stress, Anxiety, Performance, Nurse, Covid 19.

\section{Pendahuluan}

Rumah Sakit merupakan sebuah organisasi kompleks yang terdiri atas multi-disiplin ilmu yang saling berkolaborasi dalam menjalankan roda organisasinya. Permenkes Nomor 4 tahun 2018 tentang Kewajiban Rumah Sakit dan Kewajiban Pasien, menyebutkan bahwa salah satu kewajiban rumah sakit adalah memberikan pelayanan kesehatan yang aman, bermutu, anti-diskriminasi dan efektif dengan mengutamakan kepentingan pasien sesuai dengan standar pelayanan.

Salah satu profesi yang mempunyai peran penting di rumah sakit adalah perawat. Tenaga keperawatan merupakan sumber daya manusia (SDM) dengan prosentase jumlah terbanyak dari komposisi ketenagaan di rumah sakit dan merupakan SDM rumah sakit yang paling lama berinteraksi dengan klien. Asuhan keperawatan di rumah sakit merupakan layanan yang harus berjalan terus menerus 24 jam secara kontinyu, mendampingi dan memonitor kesehatan pasien secara berkesinambungan dengan asuhan keperawatan yang komprehensif dan professional (Sondang, 2003).

Permasalahan yang sering dihadapi oleh perawat di rumah sakit adalah tingginya beban kerja. Semakin besarnya beban kerja yang tidak seimbang dengan kemampuan baik fisik, psikis maupun keahlian dan waktu yang tersedia maka akan menjadi sumber stress (Azizah, 2009).

Mewabahnya virus Corona 19 yang telah menjadi pandemic global, termasuk di Indonesia yang telah menjangkiti ratusan ribu orang tersebut membuat bertambahnya beban kerja tenaga medis, termasuk perawat. Tingginya tingkat penyebaran dan belum ditemukannya vaksin atau antivirusnya membuat siapapun bisa tertular dan menularkan Covid 19 ini.

Perawat, sebagai salah satu garda terdepan dalam penanganan Covid 19 terutama untuk merawat pasien yang terinfeksi virus tersebut mempunyai tanggung jawab profesi yang besar dan harus terjaga produktivitas dan kinerjanya. Namun keadaan yang tidak nyaman, tidak aman dan penuh kekhawatiran dapat menimbulkan ketakutan, kecemasan dan kecenderungan stress (Himawan, 2005). keadaan yang di luar kontrol individu untuk diselasaikan sumber permasalahan atau penyebabnya maka dapat memicu potensi terjadinya gangguan psikologis lanjutan apabila tidak segera dilakukan penangganan. Kemudian akhirnya dapat mempengaruhi kinerja individu.

Penelitian ini beranjak dari fenomena pandemic Covid 19 yang menyerang dunia, termasuk Indonesia. Berdasarkan pengamatan dan analisa terhadap kondisi psikologis tenaga perawat yang merawat pasien Covid 19, 
maka peneliti ingin meninjau lebih jauh "Pengaruh Stres dan Kecemasan Terhadap Kinerja Perawat Di Ruang Isolasi Covid 19 Gedung Anggrek RSUP Fatmawati Jakarta Tahun 2020".

\section{Metode}

Kinerja perawat adalah aktivitas perawat dalam mengimplementasikan sebaik-baiknya wewenang, tugas dan tanggung jawab profesi atau keahlianya dalam upaya mewujudkan tujuan dan sasaran unit organisasi (Suroso, 2011). Penilaian kinerja perawat merupakan sesuatu yang dapat diukur secara objektif sehingga dapai memacu prestasi untuk lebih tinggi lagi, meliputi aspek kemampuan/ability, motivasi/motivation dan kesempatan berprestasi/opportunity to perform (Faizin dan Winarsih, 2008).

Stres adalah respon individu terhadap kejadian pemicu stres (stresor) yang mengganggu, mengancam, bahkan membahayakan yang dipengaruhi oleh lingkungan (Santrock, 2003). Respon individu terhadap stress dapat berdampak pada aspek fisik, emosional, kognisi dan interpersonal yang meliputi indicator : sulit untuk santai (difficulty relaxing), munculnya kegugupan (nervous arousal), mudah marah atau gelisah (easily upset/agitated), perasaan mengganggu (irritable/over-reactive), dan tidak sabar (impatient). (Hardjana, 1994).

Kecemasan adalah perasaan subjektif yang menggelisahkan sebagai reaksi umum dari ketidakmampuan mengatasi suatu masalah atau tidak adanya rasa aman serta kekhawatiran bahwa sesuatu yang buruk akan terjadi. Indikator kecemasan dalam penelitian ini meliputi simptom suasana hati, simptom kognitif dan simptom motorik.

Metode Analisis Data menggunakan 1) metode analisis deskriptif, yaitu suatu metode penelitian yang memberikan gambaran lebih mendalam tentang Pengaruh Stres dan Kecemasan Terhadap Kinerja Perawat Di Ruang Isolasi Covid 19 Gedung Anggrek Lantai 6 RSUP Fatmawati. 2) Analisis Bivariat, untuk mengetahui pengaruh stres terhadap kinerja, pengaruh kecemasan terhadap kinerja, pengaruh lingkungan stres dan kecemasan terhadap kinerja perawat di Ruang Isolasi Covid 19 Gedung Anggrek RSUP Fatmawati Jakarta Tahun 2020.

Instrumen yang digunakan dalam penelitian ini berupa kuisioner terstruktur yang berisi pernyataan atau pertanyaan yang dipilih oleh responden. Menggunakan format tipe Linkert yang dirancang untuk memungkinkan reponden menjawab dalam berbagai tingkatan pada item pertanyaan. Kelayakan instrumen dilakukan dengan uji validitas, yaitu prosedur pengujian alat ukur yang digunakan untuk mendapatkan data (mengukur) yang valid dan dapat digunakan untuk mengukur apa yang hendak diukur; dan Uji reliabilitas, yaitu pengujian yang menunjukkan sejauh mana alat ukur tersebut stabilitas dan konsistensi untuk digunakan, sehingga memberikan hasil yang relatif konsisten jika pengukuran tersebut diulangi.

Pengolahan data melalui empat tahap yaitu data editing, data coding, data entry dan data cleaning.

Pengujian Hipotesis untuk mengetahui kebermaknaan dari hasil pengujian tersebut dilihat dari value, kemudian dibandingkan dengan nilai $\alpha=$ $5 \%$ atau dengan ketentuan : 
1. Jika value $\geq$ nilai $\alpha=0,05$ maka $H_{0}$ diterima, tidak ada pengaruh stres terhadap kinerja.

Jika value $<$ nilai $\alpha=0,05$ maka $\mathrm{H}_{0}$ ditolak, yang berarti ada pengaruh stres terhadap kinerja

2. Jika value $\geq$ nilai $\alpha=0,05$ maka $H_{0}$ diterima, tidak ada pengaruh kecemasan terhadap kinerja.

\section{Hasil}

\section{Hasil Analisis Univariat}

Tabel 1. Distribusi Responden berdasarkan usia

\begin{tabular}{ccc}
\hline $\begin{array}{c}\text { Kelompok } \\
\text { usia }\end{array}$ & Frekuensi & Presentase \\
\hline $22-27$ & 12 & 23,6 \\
$28-33$ & 14 & 27,4 \\
$34-39$ & 14 & 27,4 \\
$40-45$ & 6 & 11,8 \\
$46-51$ & 5 & 9,8 \\
Total & 51 & $100 \%$ \\
\hline
\end{tabular}

Deskripsi responden dalam penelitian ini berdasarkan usia menyatakan bahwa ratarata usia 28 - 39 tahun, dengan klasifikasi

Tabel 2. Deskripsi subjek berdasarkan jenis kelamin

\begin{tabular}{lcc}
\hline Karakteristik Subjek & $\mathrm{N}$ & $\%$ \\
\hline Jenis Kelamin & & \\
Laki-laki & 7 & $13,7 \%$ \\
Perempuan & 44 & $86,3 \&$ \\
\hline
\end{tabular}

Tabel 3. Deskripsi subjek berdasarkan lama kerja

\begin{tabular}{lll}
\hline $\begin{array}{l}\text { Karakteristik } \\
\text { Subjek }\end{array}$ & $\mathrm{N}$ & $\%$ \\
\hline Lama Kerja & & \\
1-10 Tahun & 33 & 64,7 \\
11-30 Tahun & 18 & 35,3 \\
\hline
\end{tabular}

Jika value $<$ nilai $\alpha=0,05$ maka $\mathrm{H}_{0}$ ditolak, ada pengaruh kecemasan terhadap kinerja

3. Jika value $\geq$ nilai $\alpha=0,05$ maka $\mathrm{H}_{0}$ diterima, tidak ada pengaruh stres dan kecemasan terhadap kinerja Jika value $<$ nilai $\alpha=0,05$ maka $\mathrm{H}_{0}$ ditolak, yang berarti ada pengaruh stres

perawat termuda berusia 22 tahun dan usia tertua 51 tahun. 
Deskripsi responden dalam penelitian ini berdasarkan tabel 2 jenis kelamin di atas menyatakan bahwa tenaga keperawatan yang bekerja berjenis kelamin laki-laki berjumlah 7 orang dan perempuan berjumlah 44 orang dari total populasi perawat 51 orang.

Tabel 4. Tabel Distribusi Responden berdasarkan Tingkat Pendidikan

\begin{tabular}{lcc}
\hline $\begin{array}{l}\text { Karakteristik } \\
\text { Subjek }\end{array}$ & $\mathrm{N}$ & $\%$ \\
\hline $\begin{array}{l}\text { Tingkat Pendidikan } \\
\text { D3 }\end{array}$ & 28 & 54,9 \\
\hline S1/D4 & 17 & 33,3 \\
Ners & 5 & 9,8 \\
S2 & 1 & 2,0 \\
\hline
\end{tabular}

Berdasarkan hasil tabel 5.4 menyatakan bahwa tenaga keperawatan yang bekerja dengan tingkat pendidikan D3 sejumlah 28

Tabel 5. Distribusi Berdasarkan Shift Kerja

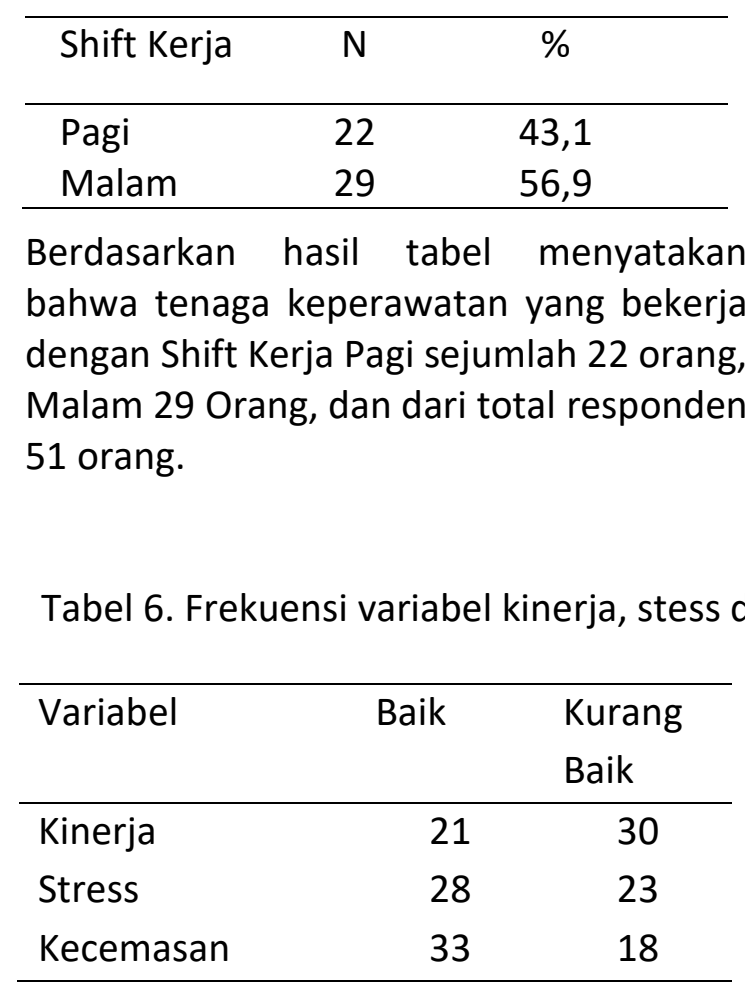

orang, S1/D4 17 Orang, Ners sebanyak lima orang dan S2 sebanyak satu orang dari total responden sebanyak 51 orang.

\begin{abstract}
Berdasarkan lama bekerja menyatakan bahwatenaga keperawatan dengan Lama Kerja1-10 Tahun sejumlah 33 orang, 11-30 Tahun 18 Orang dari total responden 51 orang.
\end{abstract}


Berikan hasil table 5.5 menyatakan bahwa variabel kinerja Baik sejumlah 21 orang, kurang baik sejumlah 30 orang, variabel Stress Baik sejumlah 28 orang, kurang baik sejumlah 23 orang, variabel kinerja Baik sejumlah 33 orang, kurang baik sejumlah 18 orang $(\mathrm{N}=51)$ orang.

Tabel 7. Variabel kinerja berdasarkan elemen instrument pengukuran

\begin{tabular}{|c|c|c|c|c|}
\hline \multirow[t]{2}{*}{ No. } & \multirow[t]{2}{*}{$\begin{array}{l}\text { Item } \\
\text { Kinerja }\end{array}$} & \multicolumn{2}{|c|}{$\begin{array}{l}\text { Frekuensi } \\
\text { penilaian }\end{array}$} & \multirow[t]{2}{*}{ Total } \\
\hline & & Baik & $\begin{array}{l}\text { Kuran } \\
\text { g Baik }\end{array}$ & \\
\hline 1 & $\begin{array}{l}\text { Saya } \\
\text { melaksana } \\
\text { kan } \\
\text { pengkajian } \\
\text { pasien } \\
\text { saat baru } \\
\text { masuk } \\
\text { Rumah } \\
\text { sakit }\end{array}$ & 51 & 0 & 51 \\
\hline 2 & $\begin{array}{l}\text { Saya } \\
\text { melengka } \\
\text { pi setiap } \\
\text { format } \\
\text { catatan } \\
\text { pengkajian } \\
\text { pasien } \\
\text { dengan } \\
\text { tepat }\end{array}$ & 51 & 0 & 51 \\
\hline 3 & \begin{tabular}{l} 
Saya \\
me \\
ngucapkan \\
\multicolumn{1}{c}{ sal } \\
am pada \\
pasien \\
sebelum \\
melakukan \\
pengkajian
\end{tabular} & 49 & 2 & 51 \\
\hline 4 & $\begin{array}{l}\text { Saya } \\
\text { menyusun } \\
\text { diagnosa } \\
\text { keperawat } \\
\text { an }\end{array}$ & 49 & 2 & 51 \\
\hline
\end{tabular}


mengandu

ng unsur:

masalah,

penyebab

masalah,

tanda

serta

gejala

5 Saya

$48 \quad 3$

51

menyusun

diagnosa

keperawat

an sesuai

dengan

kewenang

an

perawat

6 Saya

melakukan

$\begin{array}{lll}44 & 7 & 51\end{array}$

pengkajian

secara

menyeluru

$\mathrm{h}$

mencakup

bio-psiko-

sosio-

spiritual

7 Saya

$47 \quad 4$

51

melakukan

pengkajian

sesuai

dengan

standar

Pengkajian

yang telah

ditetapkan

8 Saya $46 \quad 5$

merumusk

an

diagnosa

keperawat

an dengan

berdasark

http://ejournal.urindo.ac.id/index.php/MARSI 


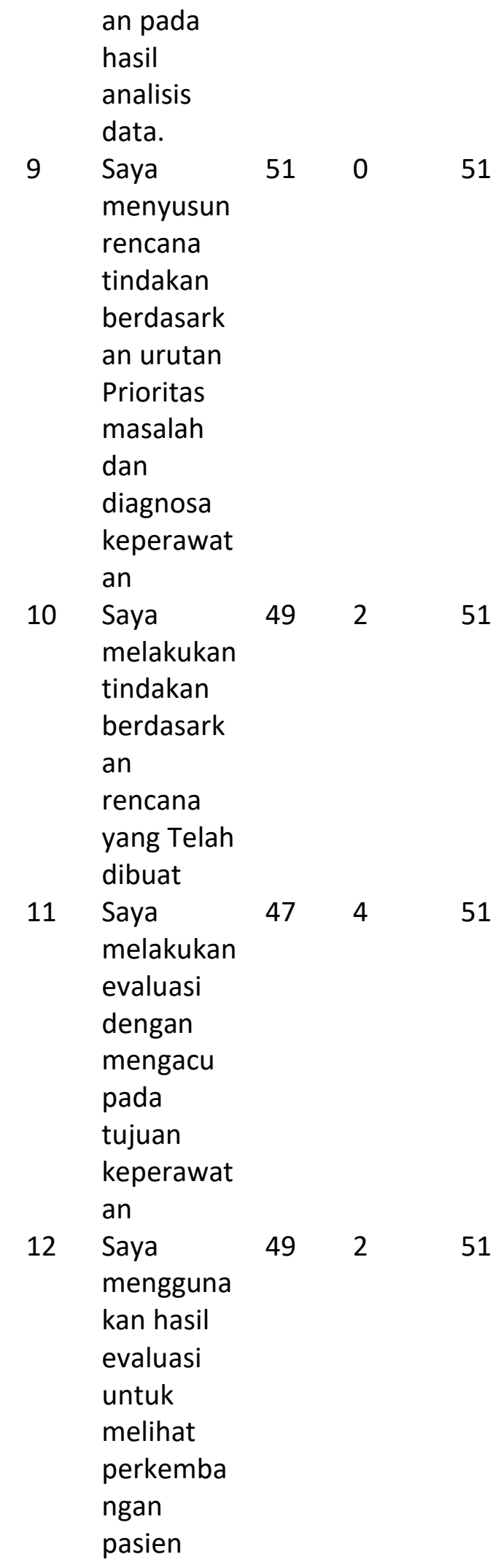




\begin{tabular}{|c|c|c|c|}
\hline 13 & $\begin{array}{l}\text { Saya } \\
\text { mendoku } \\
\text { mentasika } \\
\text { n hasil } \\
\text { setiap } \\
\text { selesai } \\
\text { melakukan } \\
\text { evaluasi } \\
\text { perkemba } \\
\text { ngan } \\
\text { pasien. }\end{array}$ & 51 & 0 \\
\hline 14 & $\begin{array}{l}\text { Melakuka } \\
\mathrm{n} \text { tindakan } \\
\text { keperawat } \\
\text { an dengan } \\
\text { memperha } \\
\text { tikan } \\
\text { kebersihan } \\
\text { dan } \\
\text { sterilisasi }\end{array}$ & 49 & 2 \\
\hline 15 & $\begin{array}{l}\text { Saya } \\
\text { mengutam } \\
\text { akan } \\
\text { kerapihan } \\
\text { dalam } \\
\text { berpenam } \\
\text { pilan } \\
\text { disaat jam } \\
\text { dinas }\end{array}$ & 48 & 3 \\
\hline 16 & $\begin{array}{l}\text { Saya } \\
\text { membuat } \\
\text { rencana } \\
\text { perawatan } \\
\text { terdiri dari } \\
\text { penetapan } \\
\text { prioritas } \\
\text { masalah, } \\
\text { tujuan dan } \\
\text { rencana } \\
\text { tindakan } \\
\text { keperawat } \\
\text { an }\end{array}$ & 50 & 1 \\
\hline
\end{tabular}




\begin{tabular}{|c|c|c|c|}
\hline 17 & $\begin{array}{l}\text { Saya } \\
\text { mendoron } \\
\text { g klien } \\
\text { untuk } \\
\text { mengungk } \\
\text { apkan } \\
\text { perasaann } \\
\text { ya pada } \\
\text { saat } \\
\text { pengkajian }\end{array}$ & 49 & 2 \\
\hline 18 & $\begin{array}{l}\text { Saya } \\
\text { menggali } \\
\text { informasi } \\
\text { tentang } \\
\text { riwayat } \\
\text { keperawat } \\
\text { an klien }\end{array}$ & 49 & 2 \\
\hline 19 & $\begin{array}{l}\text { Saya } \\
\text { mengguna } \\
\text { kan atribut } \\
\text { dinas } \\
\text { perawat } \\
\text { secara } \\
\text { lengkap } \\
\text { saat dinas }\end{array}$ & 50 & 1 \\
\hline 20 & $\begin{array}{l}\text { Saya } \\
\text { melakukan } \\
\text { evaluasi } \\
\text { berdasark } \\
\text { an standar } \\
\text { asuhan } \\
\text { keperawat } \\
\text { an }\end{array}$ & 49 & 2 \\
\hline 21 & \begin{tabular}{l} 
Saya \\
menyusun \\
\multicolumn{1}{c}{ per } \\
encanaan \\
evaluasi \\
hasil dari \\
intervensi \\
secara \\
komprehe \\
nsif, tepat
\end{tabular} & 49 & 2 \\
\hline
\end{tabular}


waktu dan

terus

menerus

22 Saya $49 \quad 2$

mengutam

akan

kepenting

an klien

atau dinas

Dari pada

kepenting

an pribadi

23 Saya

mendoku

mentasika

$n$ hasil

evaluasi

tindakan

keperawat

an

Berdasarkan unsur-unsur tabel di atas dapat disimpulkan secara umum sudah baik, namun yang menunjukan kondisinya paling rendah terdapat di instrumen melakukan pengkajian secara menyeluruh mencakup bio-psiko-sosio-spiritual.

Tabel 8. Variabel stres berdasarkan elemen instrument pengukuran

\begin{tabular}{|c|c|c|c|c|}
\hline \multirow[t]{2}{*}{ No. } & \multirow[t]{2}{*}{ Item Stress } & \multicolumn{2}{|c|}{$\begin{array}{l}\text { Frekuensi } \\
\text { penilaian }\end{array}$} & \multirow[t]{2}{*}{ Total } \\
\hline & & Baik & $\begin{array}{l}\text { Kurang } \\
\text { Baik }\end{array}$ & \\
\hline 1 & $\begin{array}{ll}\text { Menjadi } & \text { marah } \\
\text { karena } & \text { hal-hal } \\
\text { kecil } & \end{array}$ & 51 & 0 & 51 \\
\hline 2 & $\begin{array}{l}\text { Mulut } \\
\text { kering }\end{array}$ & 49 & 2 & 51 \\
\hline 3 & $\begin{array}{l}\text { Tidak dapat } \\
\text { melihat hal yang } \\
\text { positif }\end{array}$ & 50 & 1 & 51 \\
\hline 4 & $\begin{array}{l}\text { Merasakan } \\
\text { gangguan dalam } \\
\text { bernapas }\end{array}$ & 51 & 0 & 51 \\
\hline
\end{tabular}


5 Merasa sepertinya $51 \quad 0 \quad 51$

tidak kuat lagi

untuk melakukan

kegiatan

6 Cenderung

bereaksi

berlebihan pada

situasi

7 Kelemahan

8 Kesulitan untuk $50 \quad 1 \quad 51$

relaksasi/bersantai

9 Cemas yang $\begin{array}{llll}50 & 1 & 51\end{array}$

berlebihan

$\begin{array}{llll}\text { Pesimis } & 51 & 0 & 51\end{array}$

11 Mudah merasa $51 \quad 0 \quad 51$

kesal

12 Merasa banyak $51 \quad 0 \quad 51$

mengahbiskan

energi karena

cemas

13 Merasa sedih dan $51 \quad 0 \quad 51$

depresi

14 Tidak sabaran $\quad 49 \quad 2 \quad 51$

$\begin{array}{lllll}15 & \text { Kelelahan } & 47 & 4 & 51\end{array}$

16 Kehilangan minat $51 \quad 0 \quad 51$

pada banyak hal

17 Merasa diri tidak $51 \quad 0 \quad 51$

layak

18 Mudah

$51 \quad 0 \quad 51$

tersinggung

19 Berkerigat tanpa $51 \quad 0 \quad 51$

stimulasi oleh

cuaca atau latihan

fisik

20 Ketakutan tanpa $51 \quad 0 \quad 51$

alsan yang jelas

21 Merasa hidup tak $51 \quad 0 \quad 51$ berarti 
Berdasarkan unsur-unsur tabel di atas paling rendah terdapat di instrumen kesimpulannya secara umum sudah baik, kelelahan namun yang menunjukan kondisinya

Tabel 9. Variabel kecemasan berdasarkan elemen instrument pengukuran

\begin{tabular}{|c|c|c|c|c|}
\hline No. & $\begin{array}{l}\text { Item } \\
\text { kecemasan }\end{array}$ & $\begin{array}{l}\text { Frel } \\
\text { pen } \\
\text { Bai } \\
\mathrm{k}\end{array}$ & $\begin{array}{l}\text { Uensi } \\
\text { laian } \\
\text { Kura } \\
\text { ng } \\
\text { Baik }\end{array}$ & $\begin{array}{l}\text { Tot } \\
\text { al }\end{array}$ \\
\hline 1 & $\begin{array}{l}\text { Sulit untuk } \\
\text { beristirahat }\end{array}$ & 51 & 0 & 51 \\
\hline 2 & $\begin{array}{l}\text { Kesulitan } \\
\text { dalam menelan }\end{array}$ & 51 & 0 & 51 \\
\hline 3 & $\begin{array}{l}\text { Tidak dapat } \\
\text { menikmati hal- } \\
\text { hal yang saya } \\
\text { lakukan }\end{array}$ & 51 & 0 & 51 \\
\hline 4 & $\begin{array}{l}\text { Perubahan } \\
\text { kegiatan } \\
\text { jantung dan } \\
\text { denyut nadi } \\
\text { tanpa stimulasi }\end{array}$ & 51 & 0 & 51 \\
\hline 5 & $\begin{array}{l}\text { Merasa hilang } \\
\text { harapan dan } \\
\text { putus asa }\end{array}$ & 51 & 0 & 51 \\
\hline 6 & Mudah marah & 51 & 0 & 51 \\
\hline 7 & Mudah panik & 51 & 0 & 51 \\
\hline 8 & $\begin{array}{l}\text { Kesulitan untuk } \\
\text { tenang setelah } \\
\text { sesuatu yang } \\
\text { mengganggu }\end{array}$ & 51 & 0 & 51 \\
\hline 9 & $\begin{array}{l}\text { Takut diri } \\
\text { terhambat oleh } \\
\text { tugas-tugas } \\
\text { yang tidak } \\
\text { biasa dilakukan }\end{array}$ & 51 & 0 & 51 \\
\hline 10 & $\begin{array}{l}\text { sulit antusias } \\
\text { pada banyak } \\
\text { hal }\end{array}$ & 51 & 0 & 51 \\
\hline
\end{tabular}




\begin{tabular}{|c|c|c|c|c|}
\hline 11 & $\begin{array}{l}\text { Sulit untuk } \\
\text { mentoleransi } \\
\text { gangguan- } \\
\text { gangguan } \\
\text { terhadap hal } \\
\text { yang sedang } \\
\text { dilakukan }\end{array}$ & 51 & 0 & 51 \\
\hline 12 & $\begin{array}{l}\text { Berada pada } \\
\text { keadaan } \\
\text { tegang }\end{array}$ & 50 & 1 & 51 \\
\hline 13 & $\begin{array}{l}\text { Merasa tidak } \\
\text { berharga }\end{array}$ & 51 & 0 & 51 \\
\hline 14 & $\begin{array}{l}\text { Tidak dapat } \\
\text { memaklumi hal } \\
\text { apapun yang } \\
\text { mengahalangi } \\
\text { anda untuk } \\
\text { menyelesaikan } \\
\text { hal yang anda } \\
\text { lakukan }\end{array}$ & 51 & 0 & 51 \\
\hline 15 & Ketakutan & 51 & 0 & 51 \\
\hline 16 & $\begin{array}{l}\text { Tidak ada } \\
\text { harapan untuk } \\
\text { masa depan }\end{array}$ & 51 & 0 & 51 \\
\hline 17 & $\begin{array}{l}\text { Merasa hidup } \\
\text { tidak berarti }\end{array}$ & 51 & 0 & 51 \\
\hline 18 & Mudah gelisah & 51 & 0 & 51 \\
\hline 19 & $\begin{array}{l}\text { Khawatir } \\
\text { dengan situasi } \\
\text { saat diri anda } \\
\text { mungkin } \\
\text { menjadi panik }\end{array}$ & 50 & 1 & 51 \\
\hline 20 & Gemetar & 51 & 0 & 51 \\
\hline 21 & $\begin{array}{l}\text { Sulit untuk } \\
\text { meningkatkan } \\
\text { inisiatif dalam } \\
\text { melakukan } \\
\text { sesuatu }\end{array}$ & 51 & 0 & 51 \\
\hline
\end{tabular}

Berdasarkan unsur-unsur tabel diatas namun yang menunjukan kondisinya kesimpulannya secara umum sudah baik, paling rendah terdapat di instrumen 
Berada pada keadaan tegang dan Khawatir dengan situasi saat diri anda mungkin menjadi panik dan mempermalukan diri sendiri.

Tabel 5.9. Nilai Descriptives Variabel stres, kecemasan dan kinerja

\begin{tabular}{|c|c|c|c|c|}
\hline $\begin{array}{c}\text { Karakteri } \\
\text { stik } \\
\text { Variabel }\end{array}$ & Mean & $\begin{array}{c}\mathrm{Mi} \\
\mathrm{n}\end{array}$ & $\begin{array}{c}\text { Ma } \\
\mathrm{x}\end{array}$ & Range \\
\hline Stres & 12 & 0 & 39 & 39 \\
\hline $\begin{array}{c}\text { Kecemas } \\
\text { an }\end{array}$ & 9,1 & 0 & 37 & 37 \\
\hline Kinerja & 82,5 & 56 & 92 & 36 \\
\hline
\end{tabular}

Berdasarkan hasil tabel menyatakan bahwa rata-rata variabel kinerja meliliki rata-rata 82,5 dengan nilai minimum 56 , nilai maksismum 92 dengan range 36, variabel kecemasan meliliki rata-rata 9, dengan nilai minimum 0 , maksismum 37 dengan range 37 , dan variabel Stress ratarata 12 dengan nilai minimum 0 , maksimum 39, dengan range 39.

\section{Hasil Analisis Bivariat}

Tabel 10. Normalitas Distribusi variabel Jenis kelamin, usia, pendidikan, shift kerja, lama kerja, stress dan kecemasan terhadap kinerja

Berdasarkan hasil tabel di atas menyatakan bahwa Jenis kelamin 0,013>0,05, Usia $0,262>0,05$, Pendidikan 0,078 $>0,05$, Shift Kerja 0,019>0,05 dan Lama Kerja $0,200>0,05$ adalah terdistribusi normal. Mengingat data yang normal maka digunakan uji Regresi.

Tabel 11. Correlations Distribusi variabel Karakteristik individu terhadap kinerja

\begin{tabular}{lcc}
\hline Variabel & Sig. & Keterangan \\
\hline Umur & 0,80 & Tidak ada korelasi \\
Shift Kerja & 0,42 & Tidak ada korelasi \\
Lama Kerja & 026 & Ada korelasi \\
Stres & 0,002 & Ada korelasi \\
Kecemasan & 0,001 & Ada korelasi \\
\hline
\end{tabular}

Berdasarkan hasil tabel di atas menyatakan bahwa variabel Umur dan Shift Kerja tidak ada korelasi terhadap Kinerja. sedangkan variabel Lama Kerja, Stress dan Kecemasan terjadi atau ada korelasi (signifikan) $<0,05$ 
yang berarti $\mathrm{HO}$ ditolak dan Ha diterima terhadap kine

Tabel 12. Analisis regresi linier berganda

\begin{tabular}{|c|c|c|c|}
\hline Variabel & $\begin{array}{c}\text { Coefficients } \\
\text { Kinerja }\end{array}$ & Sig & $\begin{array}{c}95,0 \% \\
\text { Confidence } \\
\text { Interval } \\
\text { For B }\end{array}$ \\
\hline Kinerja & 84.292 & 000 & $\begin{array}{l}70.797- \\
97.787\end{array}$ \\
\hline Kecemasan & -.395 & 184 & $-.985-.194$ \\
\hline Stress & -.005 & .984 & $-.498-.488$ \\
\hline Lama Kerja & .312 & .190 & $-.161-.784$ \\
\hline Umur & -.032 & .894 & $-.510-.447$ \\
\hline Variabel & $\begin{array}{c}\text { Hasil Uji } \\
\text { Normalitas }\end{array}$ & & eterangan \\
\hline $\begin{array}{l}\text { Jenis } \\
\text { Kelamin }\end{array}$ & 0,013 & & $\begin{array}{l}\text { rdistribusi } \\
\text { Normal }\end{array}$ \\
\hline Usia & 0,262 & & $\begin{array}{l}\text { Nordistribusi } \\
\text { Normal }\end{array}$ \\
\hline Pendidikan & 0,078 & & $\begin{array}{l}\text { rdistribusi } \\
\text { Normal }\end{array}$ \\
\hline Shift Kerja & 0,019 & & $\begin{array}{l}\text { Nordistribusi } \\
\text { Normal }\end{array}$ \\
\hline Lama Kerja & 0,200 & & $\begin{array}{l}\text { Nordistribusi } \\
\text { Normal }\end{array}$ \\
\hline Stres & 0,074 & & $\begin{array}{l}\text { Nordistribusi } \\
\text { Normal }\end{array}$ \\
\hline Kecemasan & 0,200 & & $\begin{array}{l}\text { rdistribusi } \\
\text { Normal }\end{array}$ \\
\hline
\end{tabular}

Berdasarkan hasil tabel di atas kecemasan, stress dan umur bernilai menunjukan bahwa Kinerja $(Y=84,292)$, negatif terhadap kinerja.

Kecemasan $(-0,395)$ Stress $(-0,005)$, Lama Kerja (0,312), Umur $(-0,032)$. Dimana variabel lama kerja bernilai positif terhadap kinerja sedangkan variabel

\section{Pembahasan}

Pengaruh stress terhadap kinerja berdasarkan hasil Uji correlation diketahui 
nilai Asymp. Sig adalah sebesar 0,002 < 0,05 . Dengan demikian dapat disimpulkan bahwa $\mathrm{HO}$ diterima dan $\mathrm{Ha}$ ditolak yang berarti signifikan antara stress terhadap kinerja. Stres mempunyai andil dalam kinerja sebesar $14,6 \%$ dan bernilai negative, yang mempunyai makna bahwa semakin tinggi tingkat stress maka kinerja individu akan semakin menurun. Sejalan dengan penelitian Maulana Muhammad R dan Noermijati (2018), bahwa diketahui bahwa variabel stress kerja berpengaruh signifikan negative terhadap kinerja perawat. Artinya stress kerja yang ada akan memberikan pengaruh sebaliknya pada kinerja perawat, apabila stress kerja meningkat maka kinerja perawat akan menurut dan begitu juga sebaliknya. Hal ini dibuktikan dengan nilai t-statistik (2.917) dengan $p<0.05$ serta path koefisien (0.342).

Pengaruh kecemasan terhadap kinerja berdasarkan hasil Uji correlation diketahui nilai Asymp. Sig adalah sebesar $0,001<0,05$. Dengan demikian dapat disimpulkan bahwa $\mathrm{HO}$ diterima dan $\mathrm{Ha}$ ditolak yang berarti signifikan antara kecemasan terhadap kinerja. kecemasan mempunyai andil dalam kinerja sebesar $17,5 \%$ dan bernilai negative, yang bermakna bahwa semakin tinggi kecemasan maka kinerja individu akan semakin menurun. Sejalan dengan penelitian Endah Purwaningsih (2018) yang mendapatkan hasil bahwa kecemasan mempunyai pengaruh yang signifikan terhadap kinerja.

Berdasarkan hasil tabel uji $\mathrm{F}$ pada penelitian ini didapatkan nilai $F$ hitung sebesar 3,977 dan $P$ value sebesar 0,007 dengan tingkat signifikansi 95\% $(0,05)$. Angka signifikansi ( $P$ value) sebesar $0,007<0,05$. Atas dasar perbandingan tersebut, maka HO ditolak atau berarti variabel Umur, Kecemasan, Lama Kerja, Stres mempunyai pengaruh yang signifikan terhadap variabel kinerja.

Hasil tabel Uji Regresi (Koefisien Determinasi) didapatkan bahwa besarnya pengaruh total variabel Umur, Kecemasan, Lama Kerja, Stres terhadap kinerja adalah sebesar 192 sisanya 8,07\%, diterangkan oleh faktor lain yang tidak diteliti. Uji regresi juga menunjukan bahwa $(Y=84,292)$ Kinerja, Kecemasan (-.395), Stress (-.005), Lama Kerja (.312), dan Umur (-.032). Dimana variabel lama kerja bernilai positif terhadap kinerja sedangkan variabel kecemasan, stress dan umur bernilai negatif terhadap kinerja.

Sejalan dengan Umam (2012: 211) menyatakan bahwa Segala kondisi pekerjaan yang dipersepsikan karyawan sebagai suatu tuntutan dan dapat menimbulkan stres kerja. Perubahan kondisi fisik dan psikologis seseorang sebagai akibat dari respon adaptif terhadap keadaan lingkungannya yang kemudian dapat mengganggu pelaksanaan tugastugasnya/ pekerjaannya. Sejalan dengan pendapat Umam tersebut, hal ini sesuai dengan hasil penelitian ini bahwa berdasarkan hasil analisis uji koefisien parsial (uji t) diketahui bahwa stres kerja dan kecemasan berpengaruh signifikan terhadap kinerja perawat di Ruang Rawat Inap RSUD Kota Surakarta. Hal ini terbukti dari nilai thitung $(-2,397)>$ ttabel $(-1,999)$ dengan signifikansi sebesar 0,020.

$\mathrm{Hal}$ ini juga sesuai dengan pendapat Bachrach (2004) dalam Tyczkowski, et al (2015) jika perawat mengalami stress maka akan berdampak negatif pada sikap kerja yang kurang profesional kepada pasien dan keluarganya. Selain itu stress dan kecemasan mengakibatkan emosi 
perawat yang tidak stabil. Seperti yang dijelaskan Aini (2014) bahwa stres kerja berpengaruh terhadap sikap dan perilaku perawat terkait dengan keamanan dan kenyamanan pasien. Sehingga secara keseluruhan dapat disimpulkan bahwa semakin ringan tingkat stres perawat maka perilaku dan sikap perawat terkait keamanan dan kenyamanan pasien pun akan semakin baik.

\section{Kesimpulan}

Pengaruh Stres terhadap kinerja berdasarkan hasil Uji correlation diketahui nilai Asymp. Sig adalah sebesar 0,002 > 0,05 . Dengan demikian dapat disimpulkan bahwa $\mathrm{HO}$ diterima dan $\mathrm{Ha}$ ditolak yang berarti signifikan antara stress terhadap kinerja.

Pengaruh kecemasan terhadap kinerja Berdasarkan hasil Uji Correlations diketahui nilai Asymp. Sig adalah sebesar $0,001<0,05$. Dengan demikian dapat disimpulkan bahwa $\mathrm{HO}$ ditolak dan $\mathrm{Ha}$ diterima yang berarti signifikan antara kecemasan terhadap kinerja.

Pengaruh stress dan kecemasan diuji secara bersamaan terhadap kinerja berdasarkan hasil tabel uji $F$ pada penelitian ini didapatkan nilai $F$ hitung sebesar 3,977 dan $P$ value sebesar 0,007 dengan tingkat signifikansi $95 \%(0,05)$. Angka signifikansi ( $P$ value) sebesar $0,007<0,05$. Atas dasar perbandingan tersebut, maka $\mathrm{HO}$ ditolak atau berarti variabel Umur, Kecemasan, Lama Kerja, Stres mempunyai pengaruh yang signifikan terhadap variabel kinerja.

\section{Saran}

1. Bagi Rumah Sakit
Berdasarkan hasil intrumen kinerja dalam penelitian ini, kesimpulannya secara umum sudah baik. Namun yang menunjukan kondisinya paling rendah terdapat pada instrumen pengkajian secara menyeluruh mencakup biopsiko-sosial-spiritual. Instrumen stress dan kecemasan juga menunjukkan hasil secara umum perawat dalam keadaan yang baik. Kondisi yang rendah ditunjukkan oleh instrument kelelahan, berada pada keadaan tegang dan khawatir dengan situasi saat diri menjadi panic. Dari hasil tersebut maka perlunya memperhatikan sebagai berikut :

a. Perlunya sosialisasi ulang atau memberikan supervisi lebih lanjut terhadap pendalaman pengkajian bio-psiko-sosial-spiritual yang merupakan salah satu pengkajian instrument kinerja perawat.

b. Perlunya evaluasi pendalaman materi kelengkapan administrasi pasien.

C. Meminimalisir factor - factor yang dapat menjadi pencetus timbulnya stress, seperti yang digambarkan dari hasil analisis instrument stes yaitu kelelahan. Nilai coefficient stress terhadap kinerja sebesar 0,392 dikategorikan mempunyai pengaruh yang sangat moderat.

d. Memberikan rasa aman dan nyaman kepada perawat sehingga tidak terjadi ketegangan dan kekhawatiran yang dapat menimbulkan kecemasan, seperti yang ditunjukkan dari hasil analisa instrument kecemasan dalam penelitian ini. Meskipun nilai coefficient kecemasan terhadap kinerja tergolong lemah, yaitu 190 
0,163 tetapi memiliki kontribusi negative terhadap kinerja.

e. Perlu adanya kajian dan eveluasi mengenai perencanaan jumlah SDM perawat yang bertugas shift di ruangan isolasi Covid 19. Diketahui dalam penelitian ini bahwa variabel lamanya jam kerja / shift mempunyai pengaruh terhadap kinerja. Faktor shift yang tidak sesuai dengan kapasitas dan beban kerja yang tinggi akan menimbulkan kelelahan perawat.

2. Bagi Peneliti Selanjutnya

Berdasarkan hasil data statistik pengaruh stress dan kecemasan terhadap kinerja perawat di ruang isolasi Covid-19 di Lantai 6 Gedung Anggrek RSUP Fatmawati, bahwa stress mempunyai pengaruh terhadap kinerja sebesar 14,6 persen dan kecemasan 17,5 persen, sehingga perlu adanya penelitian dan analisa faktor lain yang mempengaruhi kinerja perawat seperti faktor motivasi diri, kebijakan organisasi, kepuasan kerja dan system kompensasi atau reward.

\section{Daftar Pustaka}

Aditama, T. (2004). Manajemen Administrasi Rumah Sakit. Jakarta: UI Press.

Ardani, AT, dkk (2007). Psikologi Klinis. Yogyakarta : Graha IImu.

Bambang, K. (1991). Meningkatkan Produktivitas Karyawan. Jakarta : Pustaka Binaman Pressindo.

Lovibond, S.H. \& Lovibond, P.F. (1995). Manual for the Depression Anxiety Stress Scales. (2 ${ }^{\text {nd }}$. Ed.) Sydney:
Psychology Foundation. ISBN 73341423-0.

Crawford, J.R. \& Henry, J.D. (2003). The Depression Anxiety Stress Scales (DASS): Normative data and latent structure in a large non-clinical sample. British Journal of Clinical Psychology, 42, 111-131.

Danang, P. (2009). Hubungan Stres Kerja Dengan Adaptasi Pada Perawat Di Instalasi Gawat Darurat RSUD Pandan Arang. Diakses dari http://etd.eprints.ums.ac.id

Danang. (2012). Manajemen Sumber Daya Manusia, Cetakan 1. Yogyakarta : CAPS Edy. (2008). Pengaruh Budaya Organisasional dan Lingkungan Kerja terhadap Kinerja Perawat Rumah Sakit Mata Dr. YAP Yogyakarta dengan Motivasi dan Kepuasan Kerja sebagai Variabel Pemediasi. Jurmal Ekonomi dan Bisnis. Vol 2. (No. 3) Hal 160.

Faizin, A., \& Winarsih. (2008). Hubungan tingkat pendidikan dan lama kerja perawat dengan kinerja perawat di RSUD Pandan Kabupaten Boyolali. 137-142.

Golizeck, A. (2005). 60 Second Manajemen Stres. Jakarta: Bhuana Ilmu Populer

Hardjana, A. M. (1994). Stres Tanpa Distres: Seni Mengolah Stres. Yogyakarta: Kanisius.

Himawan, A. T. (2005). Peran EmotionFocused Coping Terhadap Kecenderungan Post-Traumatic Stress Disorder Para Karyawan Yang Menyaksikan Peledakan Bom Di Depan Kedutaan Besar Australia di Jakarta Tahun 2004. Yogyakarta : Humanitas, Indonesian Psychological Journal Vol. 2, No. 2 Tahun 2005

Indriani, A. (2009). Pengaruh Konflik Peran Ganda Dan Stres Kerja Terhadap 
Kinerja Perawat Wanita RS Roemani Muhammadiyah Semarang. Semarang. Imam Syed Sohail (2005). Depression Anxiety Stress Scale (DASS) : Revisited. Departemen of Psychology, International Islamic University Malaysia

Lumbanraja, P., Nizma Cut. (2010). Pengaruh Pelatihan dan Karakteristik Pekerjaan Terhadap Prestasi Kerja Perawat di Badan Pelayanan Kesehatan Rumah Sakit Umum Daerah Langsa. Jurnal Manajemen dan Kewirausahaan. Vol 12 (No. 2) hal 143. Mangkunegara, A, P. (2009). Manajemen Sumber Daya Manusia Perusahaan. Bandung : Remaja Rosdakarya Offset. Mangkunegara, A.P. (2009). Manajemen Sumber Daya Manusia Perusahaan. Bandung: Remaja Rosdakarya.

Nawawi, H. (2006). Evaluasi dan Manajemen Kinerja di Lingkungan Perusahaan dan Industri. Yogyakarta: Gadjah Mada University Press.

Nawawi, H. (2011). Manajemen Sumber Daya Manusia untuk Bisnis yang Kompetitif. Yogyakarta: Gadjah Mada University Press.

Nurcahyani, E, dkk. (2016). Hubungan Tingkat Stres Kerja Dengan Kinerja Perawat. Malang : Jurnal Care Vol. 4, No.1, Tahun 2016, Fakultas Ilmu Kesehatan, Universitas Tribhuwana Tunggadewi

Nursalam (2008). Pendidikan dalam keperawatan. Jakarta: Salemba Medika Nursalam. (2008). Konsep dan penerapan metodologi penelitian ilmu keperawatan. Jakarta: salemba Medika.

Nursalam. (2012). Manajemen keperawatan aplikasi dalam praktik keperawatan professional. Jakarta: Salemba Medika

Peraturan Menteri Kesehatan Republik Indonesia Nomor 4 Tahun 2018 Tentang Kewajiban Rumah Sakit dan Kewajiban Pasien.

Pabundu, T. (2006). Budaya Organisasi dan Peningkatan Kinerja Perusahaan. Jakarta : Bumi Aksara.

Potter, P, A dan Perry, A, G. 2005. Buku Ajar Fundamental Keperawatan: Konsep, Proses dan Praktik Volume 1 Edisi 4. Jakarta: Penerbit Buku Kedokteran EGC.

Rasmun. (2004). Stress, koping dan adaptasi teori dan pohon masalah keperawatan. Jakarta: CV Sagung Seto.

Riadi, M. (2016). Pengertian, Jenis dan Manfaat Lingkungan Kerja. KajianPustaka.com

Santrock, J.W. (2003). AdolescentPerkembangan Remaja. Jakarta: Erlangga

Samiadji, M. A. F. E. S. (2016). Pengaruh Stres Kerja Terhadap Kinerja Perawat Melalui Kepuasan Kerja (Studi Pada Perawat Instalasi Rawat Inap Rumah Sakit Militer Kota Malang). EKeperawatan, Vol. 1, No.2, Tahun 2016 Sedarmayanti. (2001). Sumber Daya Manusia dan Produktivitas Kerja. Bandung : Mandar Maju.

Sondang, S. (2003). Teori dan Praktek Kepemimpinan. Jakarta: PT Rineka Cipta

Suarli, S., Bahtiar, Y. (2009) Manajemen keperawatan dengan pendekatan praktis. Jakarta: Erlangga.

Sugijati, dkk. (2008). Analisis Gaya Kepemimpinan Kepala Ruangan terhadap Kinerja Perawat dalam Melaksanakan Asuhan Keperawatan di 
Ruang Rawat Inap RSUD Mataram. Jurnal Kesehatan Prima. Vol 2 (No 2) Hal 329.

Suroso, S. (2011). Manajemen Sumber Daya Manusia Rumah Sakit. Jakarta : EGC

Suyanto. (2011). Metodologi dan Aplikasi Penelitian Keperawatan. Yogyakarta : Nuha Medika

Usman, H. (2011). Manajemen Teori, Praktik, dan Riset Pendidikan Edisi 3. Jakarta: Bumi Aksara.
Folkman, S., 1984., Personal Control in Stress and Coping Processes : A Theoritical Analysis. Journal of Personality and Social Psychology. Vol. 46, 838-852.

Safarino, E. P., 1998. Health Psychology: Biopsychosocial Interactions. New Jersey: John Wiley \& Sons, Inc. 